\author{
بررسى آب مجازى و ردياى اكولوزيك آب در محصول كندم آبى استان اصفهان \\ فاطمه اويسى، احمد فتاحى اردكانى * و مسعود فهرستى ثانى'

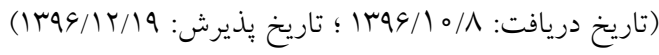

جكيده

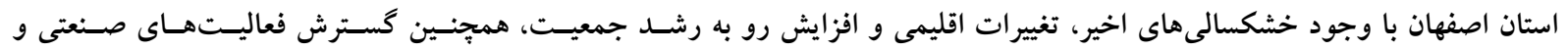

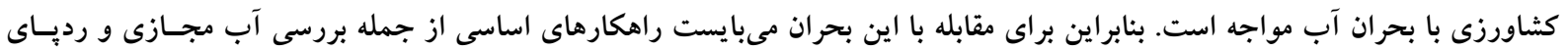

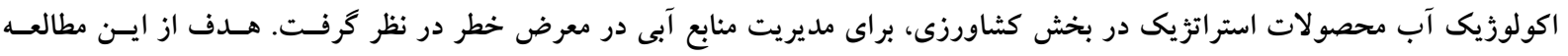

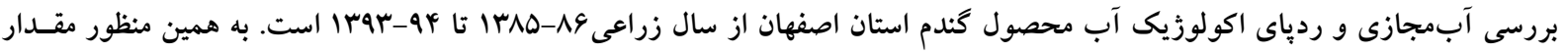

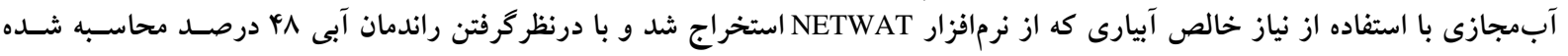

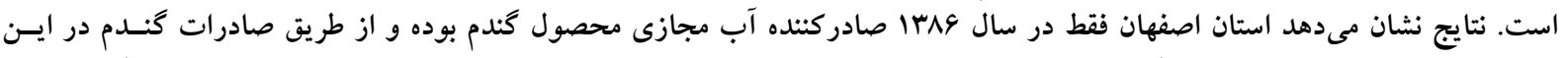

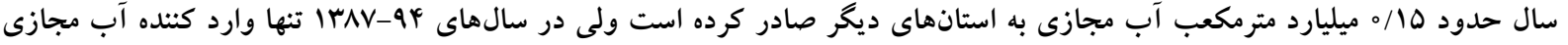

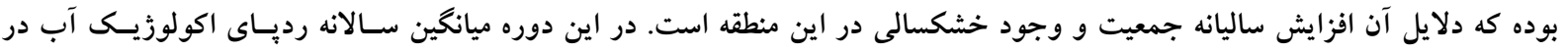

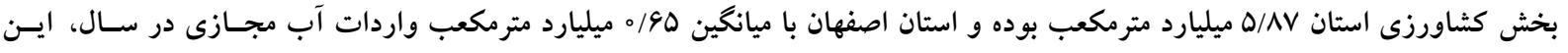

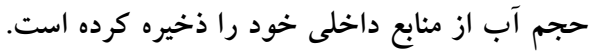

وازههاى كليدى: بهرهورى آب، شاخص شدت مصرف، شاخص وابستخى، شاخص خودكفايى، مبادله آب مجازى 
خدمات مصرف مىشود. با اين ديدكاه مىتوان در ارتبـاط بـين

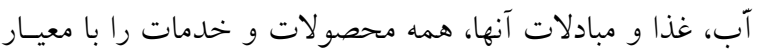
مشترى آب مصرفى سنجيد.

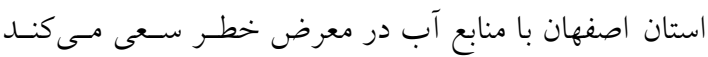

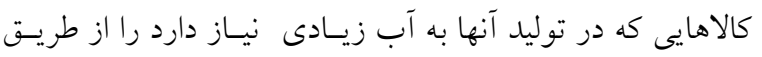

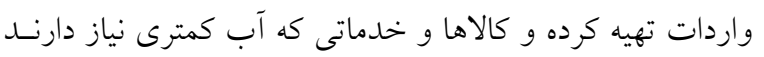

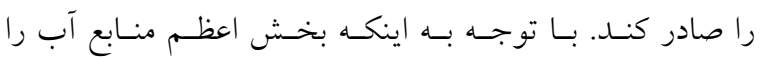

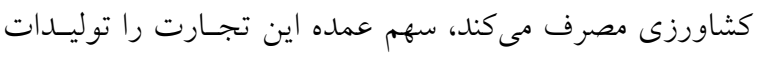
كثاورزى به خود اختصـاص داده اسـت. كشـاورزى در اسـتان

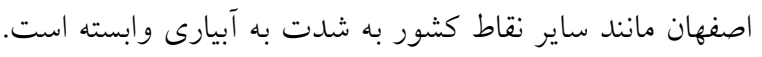

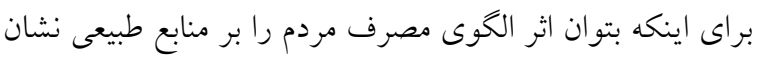

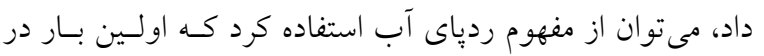

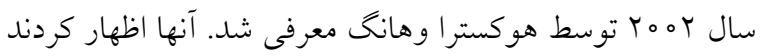
كه كل مصرف آب در داخل يك كشور به تنهايى معيار درستى

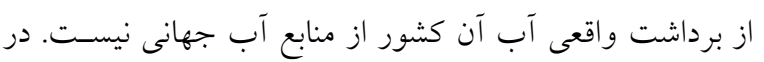

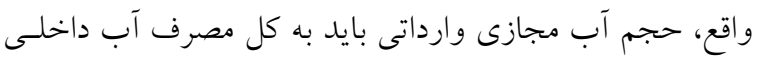

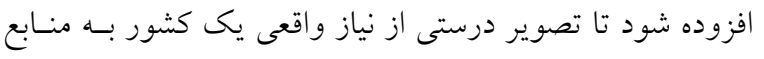

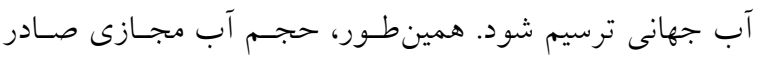

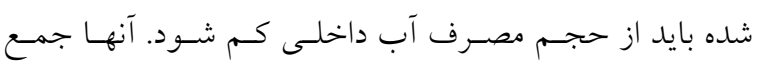

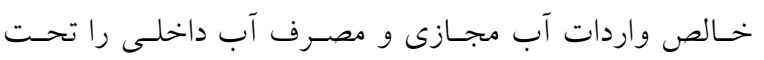

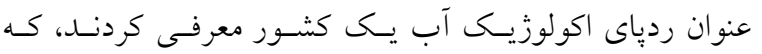

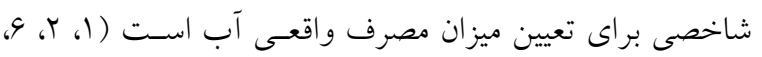

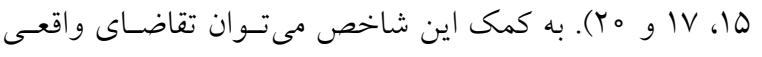

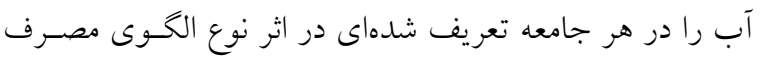

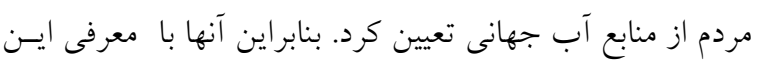

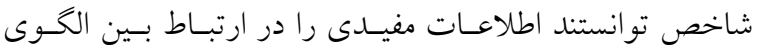

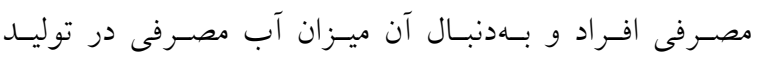

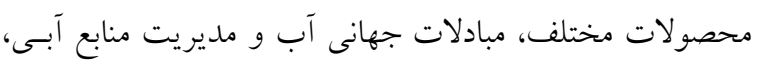

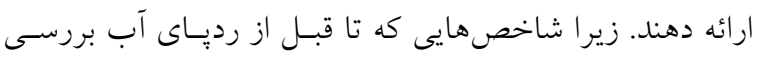

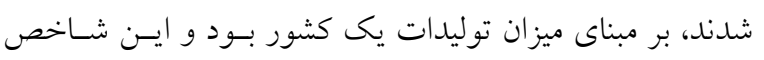

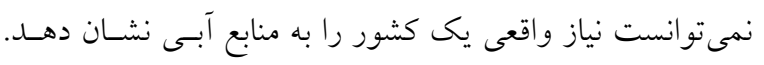

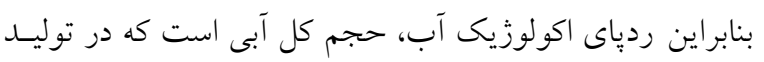

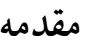

آب بهعنوان يكى از اساسى ترين عناصر حيات، امروزه با بحرانى

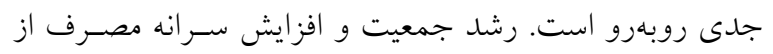
يكسو و توسعه روز افزون فعاليتهاى صنعتى و كشـاورزى از روند

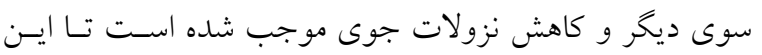

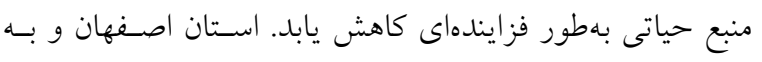

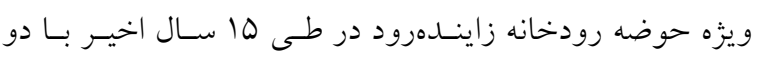
دوره خشكسالى مو اجه شده است. در دوره اول كسه طسى سـال

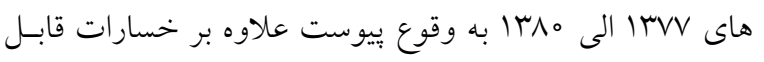
توجهى كه به بخش هاى مختلف در اسـتان وارد شــا، رودخانسه

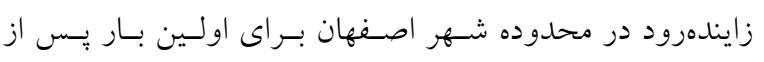

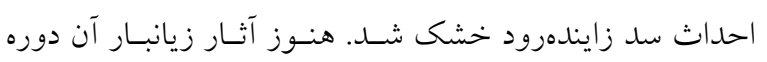
خشكسالى برطرف نشده بود كه يك دوره خشكسـالى ديخــ از از

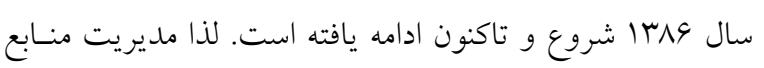

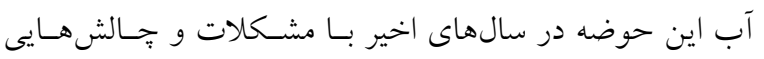

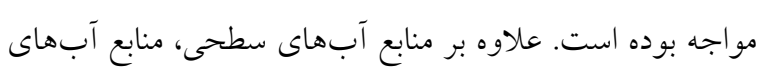

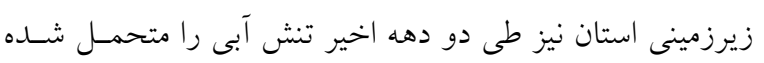

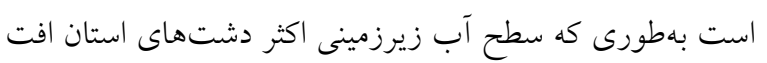

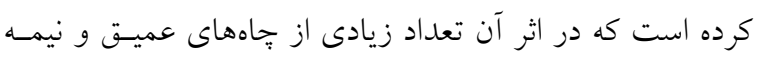

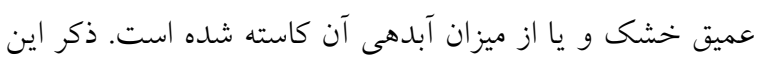

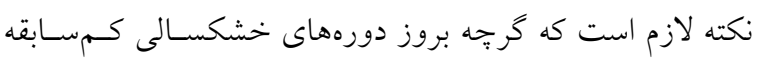
بهعنوان عامل اصلى بحران آبى اخير در استان اصـفهان قلمــداد

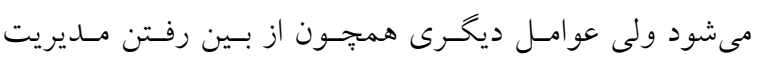

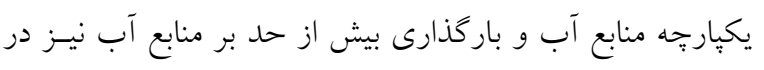

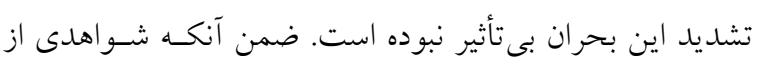
بروز تغييرات اقليمى در كل كشـور و بـهـويـزّه اسـتان اصـفهان

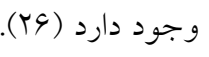

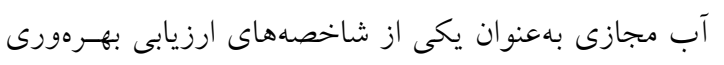

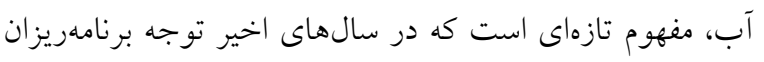

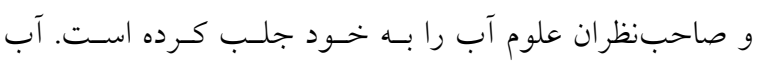

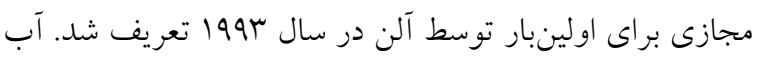

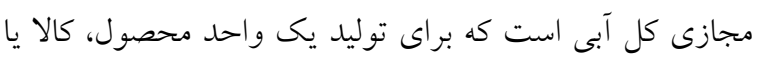




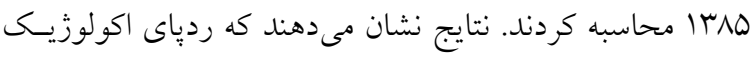

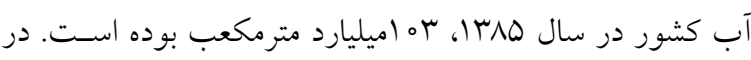

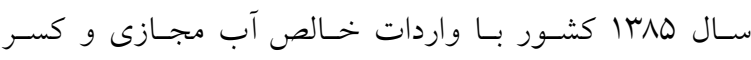

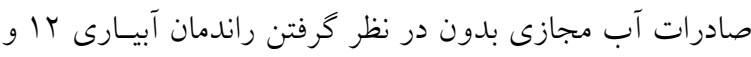

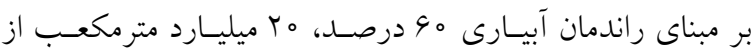

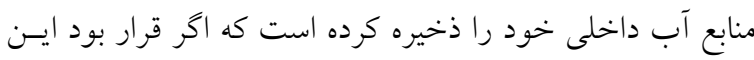

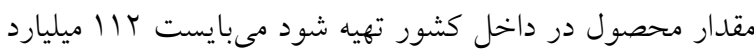

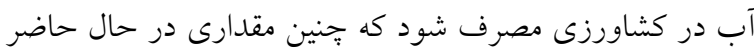
در دسترس نيست. زارعى و جعفرى (T9) در مطالعه نقش واردات و صـادرات

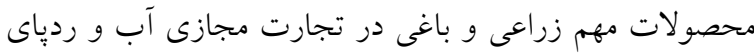

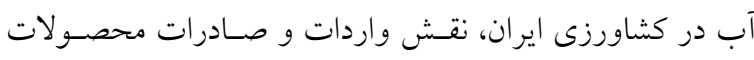
مهم كشاورزى در تراز خالص تجارت مجازى آب ايران تعيسين

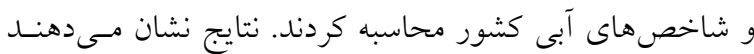

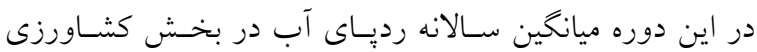

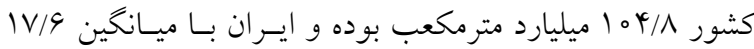
ميليارد مترمكعب واردات خالص آب مجازى در سـال، موجـب مئب

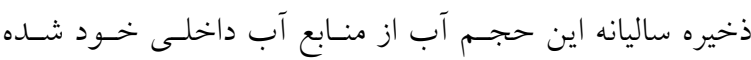

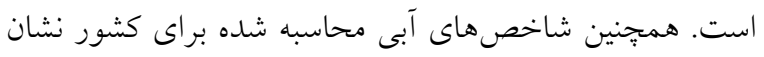

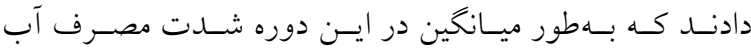

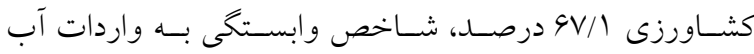

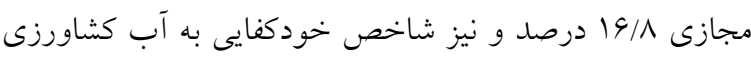

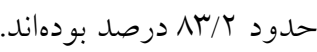
خرمىوفا و همكاران (19) در مطالعه بررسسى آب مجـازى،

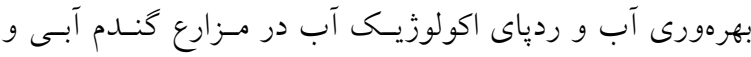
ذرت در منطقه كوزران (شهرستان كرمانشاه)، مقدار آب مجازى،

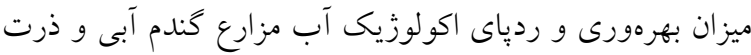

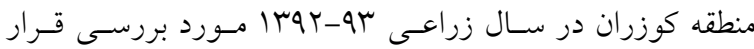

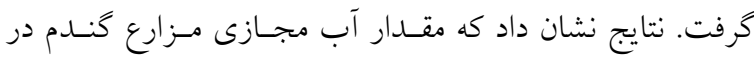

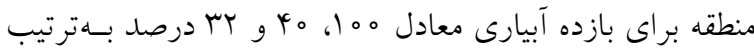

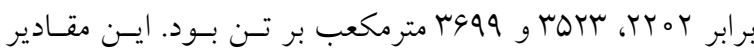

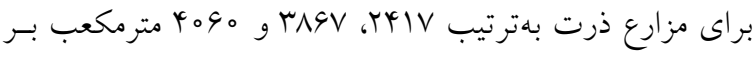

كالا و خدمات مصرفى براى ساكنان آن جامعه بـهــار مسىرود.

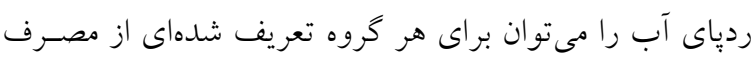

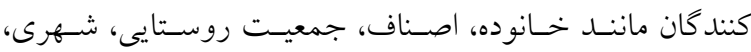
استانى و كشورى در مقياس زمانى، مكانى، داخلى و يا خارجى دانى

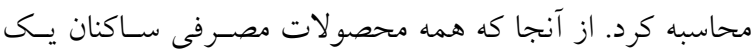

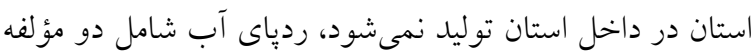

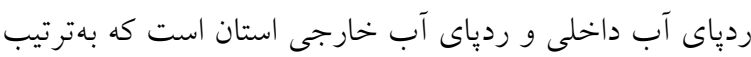

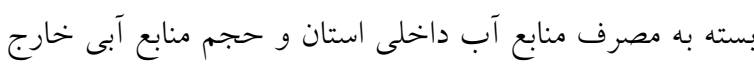

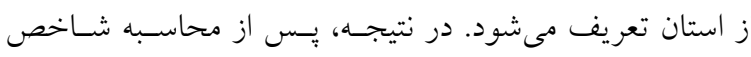

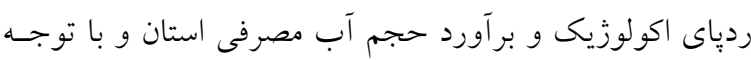

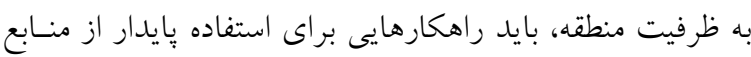

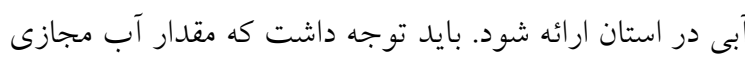

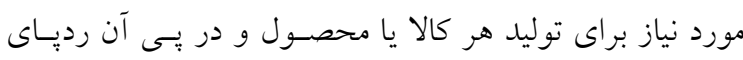

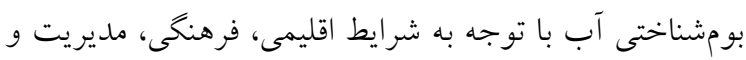

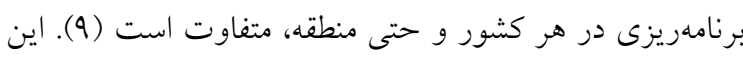

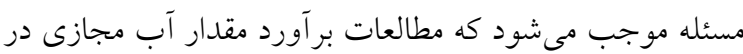
هر منطقه امرى ضرورى باشد (IT).

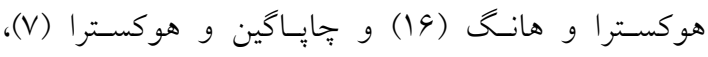

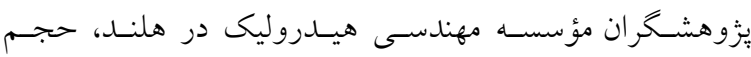

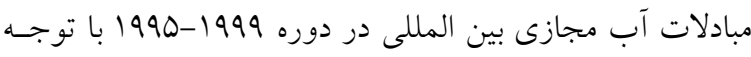

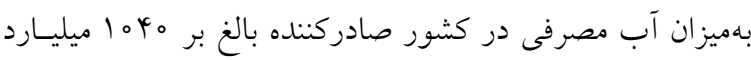

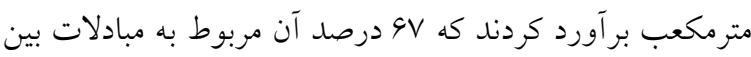

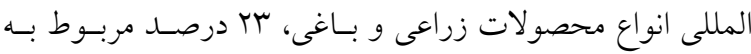
توليدات دامى و ه ا درصد مربوط به توليـدات صـنعتى اسـت. ال سدى (11)، با بررسى موقعيت كشور مصر از بعد توليد مواد غذايى و خودكفايى در توليد محصولات استراتزيك و تجـارت مجازى آب در مقايسه با ساير كشورها، نتيجه كرفــت كـه ايسن استراتزى براى مصر نيازمند تحقيقات بيشتر و درى كليه اثـرات

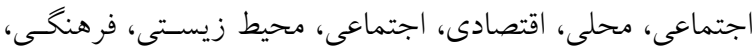

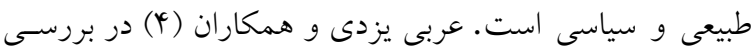

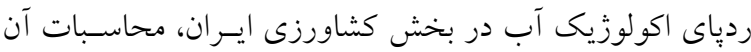
را بر مبناى دادهــاى صـادرات و واردات موادغـذايى در سـال 


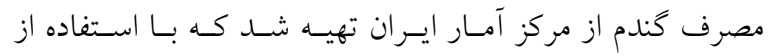

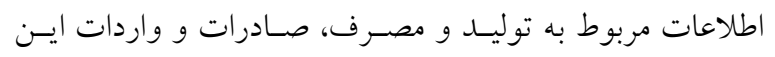

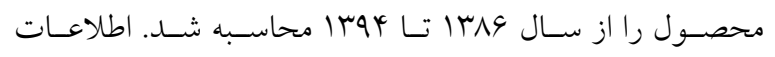

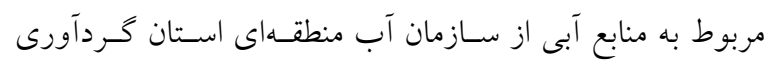

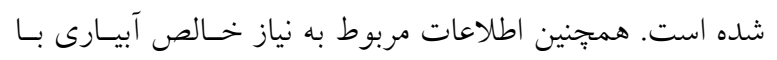

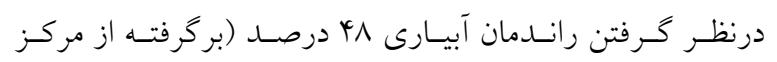

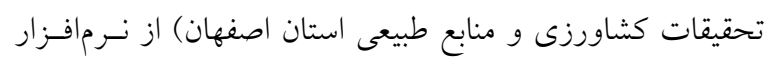

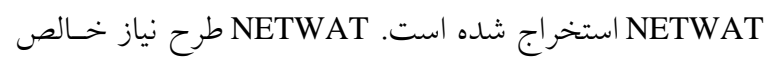

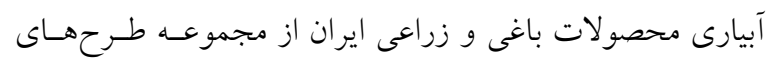

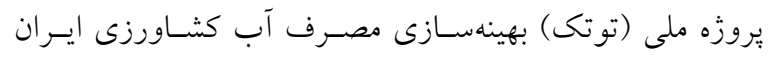

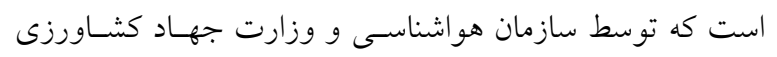

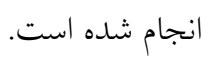

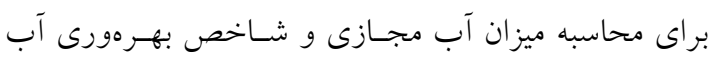
محصول گندم از رابطه (1) و (Y) استفاده شد. $\mathrm{SWD}_{\mathrm{c}}=\frac{\overline{\mathrm{CWR}_{\mathrm{C}}}}{\overline{\mathrm{CY}_{\mathrm{C}}}}$

$$
\mathrm{CWP}=\frac{1}{\mathrm{SWD}_{\mathrm{C}}}
$$

كه در آن SWD نياز ويزه آبى محصول (مترمكعب آب بهازاى هر كيلو گرم محصول)،

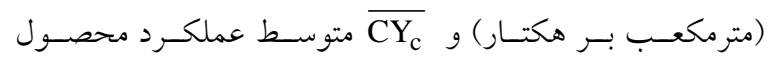

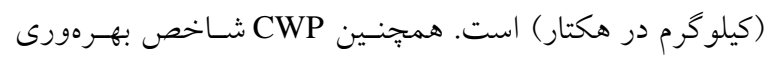
آب آست استو سبّ در معادله (r) ميزان نياز آبسى (صـرف نظـر از بـارش

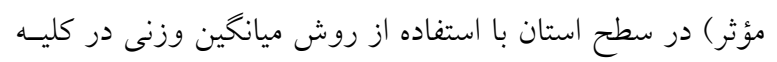
مناطق استان محاسبه شد.

$$
\overline{\mathrm{CWR}}_{\mathrm{C}}=\frac{\sum_{\mathrm{i}=1}^{\mathrm{n}} \mathrm{CWR}_{\mathrm{C} . \mathrm{i}} \times \mathrm{A}_{\mathrm{C}, \mathrm{i}}}{\mathrm{TA}_{\mathrm{C}}}
$$

كه در آن CWR نياز

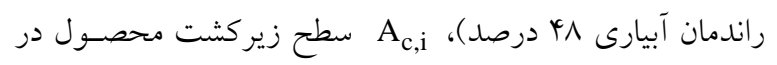

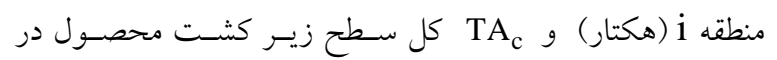
استان است.

در رابطه (†)، براى محاسبه ردياى اكولوزيــى آب در منطقـه از

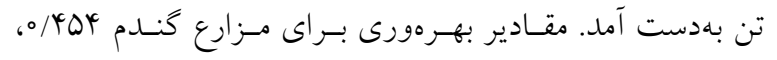
r

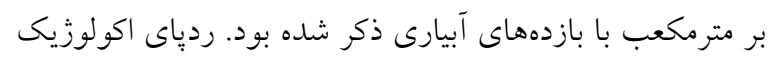

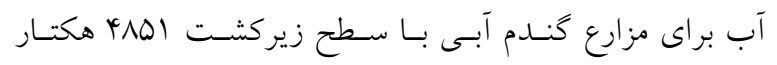

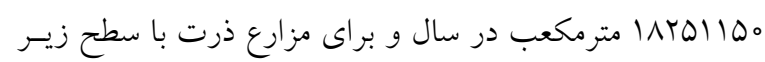

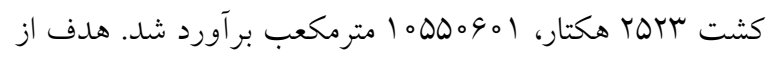

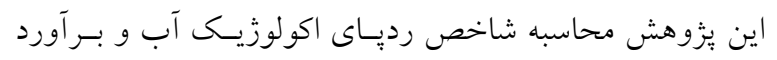

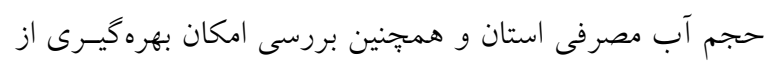

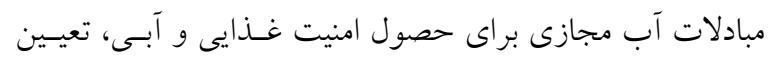

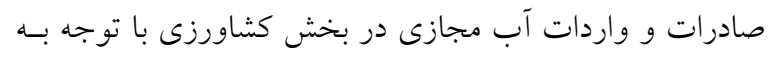

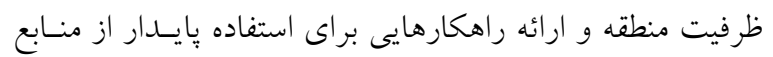
آبى در استان است.

\section{مواد و روشها - ماد}

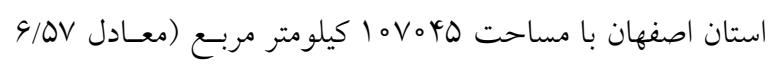

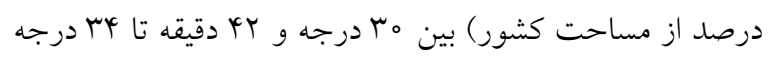

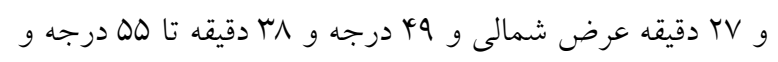

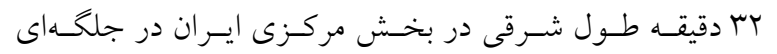

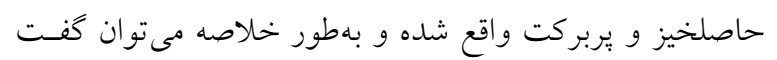

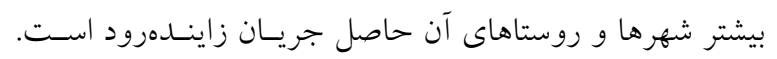

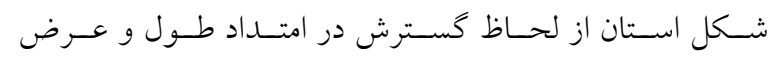

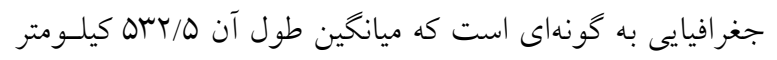

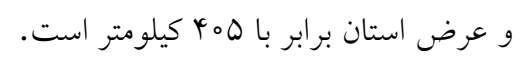

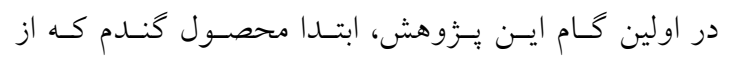

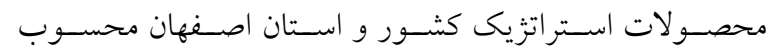

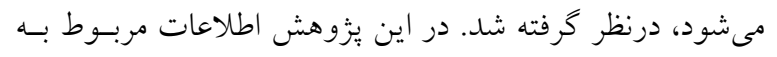

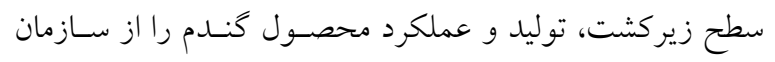

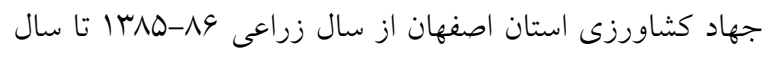

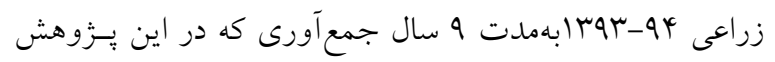

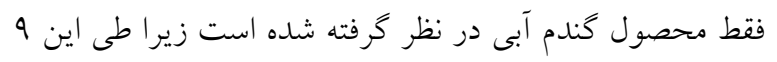

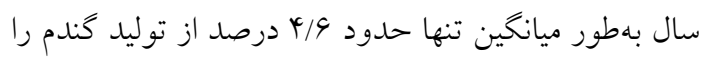
كشت ديم به خود اختصاص داده است. اطلاعات مربوط به 


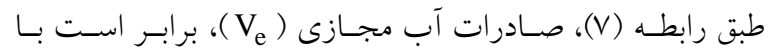

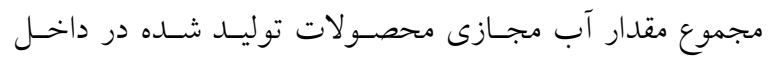

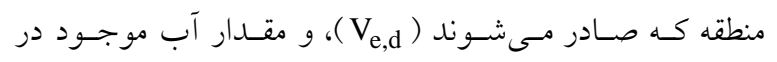

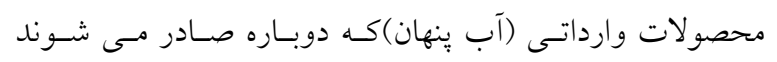
(10) $\left(V_{e, d}\right)$

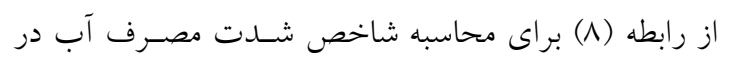
بخش كشاورزى استفاده شد (10): $\mathrm{WI}=\frac{\mathrm{WU}}{\mathrm{WA}} \times 10$

كه در اين رابطه، WU شاخص شدت مصرف آب (درصد)، WI

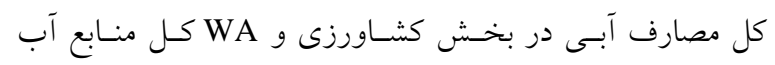

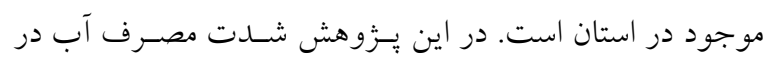

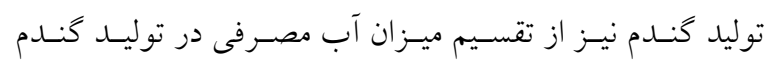

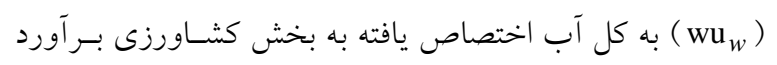

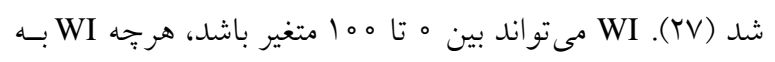

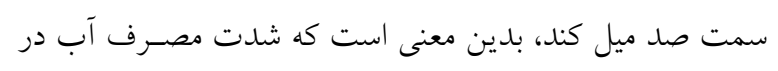

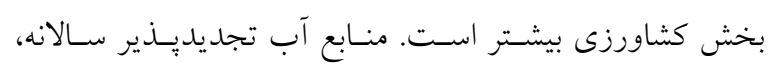

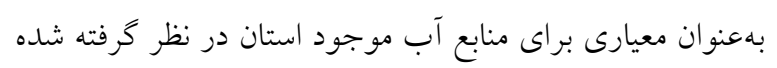
شـاخص وابستـى بــه آب (WD)، شاخصسى اسـت كـه

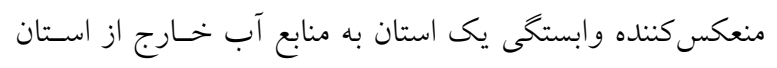
(از طرق واردات آب مجازى) است (19).

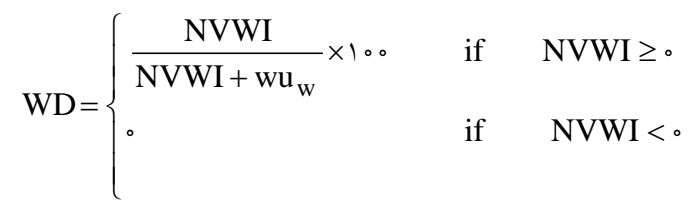

كه در اين رابطهها، NVWI ميزان خـالص واردات آب مجـازى

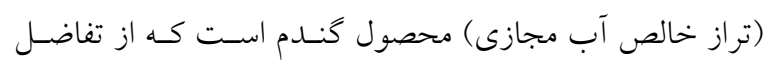

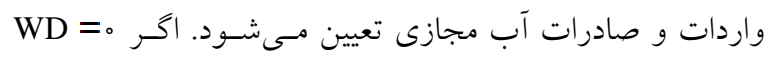
باشد، يعنى واردات و صادرات ناخالص آب مجـازى در تعـادل

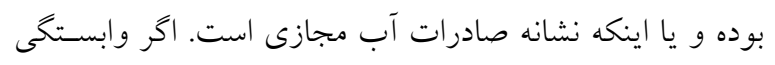

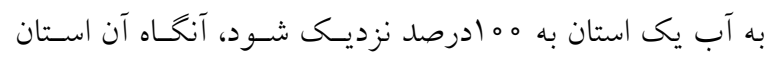

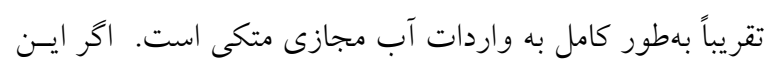

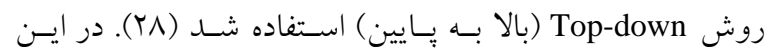

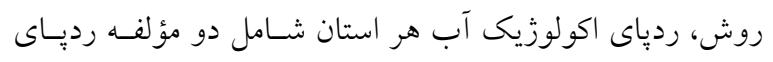

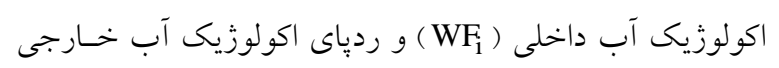
است. (WFe)

$\mathrm{WF}=\mathrm{WF}_{\mathrm{i}}+\mathrm{WF}_{\mathrm{e}}$

در رابطه (ه) ردياى اكولوزيك آب داخلى (

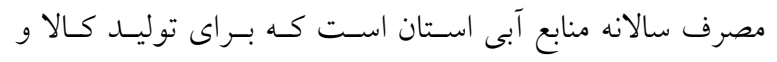
خدمات مصرفى مردم مورد استفاده قرار مى كيرد. $\mathrm{WF}_{\mathrm{i}}=\mathrm{WU}-\mathrm{V}_{\mathrm{e}, \mathrm{d}}$

در اين رابطه، از آنجا كه صادرات محصول يك استان منجر بـه

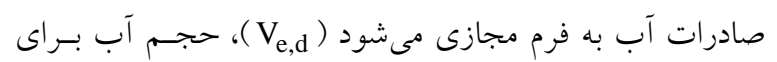

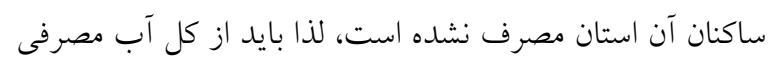
داخل استان در بخش كشاورزى (WU) كسر شـود. در خرخسه.

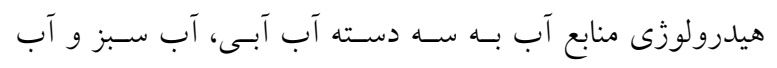

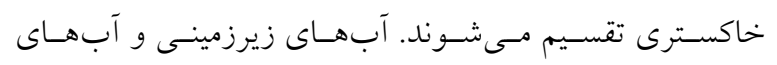

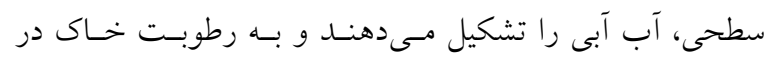

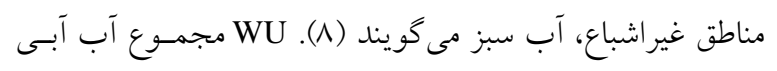

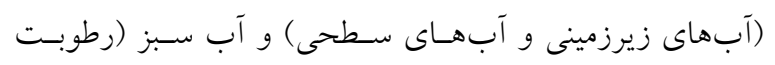

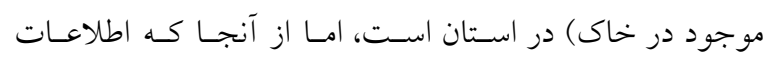

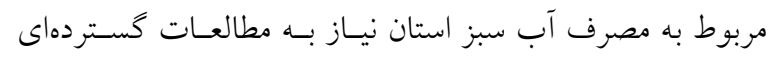

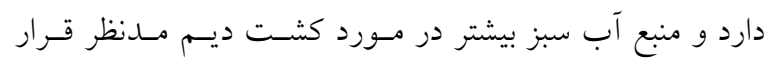

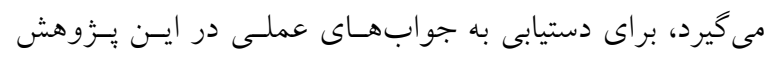

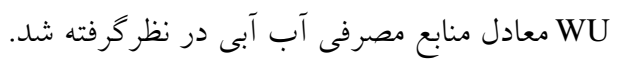
$\mathrm{WF}_{\mathrm{e}}=\mathrm{V}_{\mathrm{i}}-\mathrm{V}_{\mathrm{e}, \mathrm{r}}$

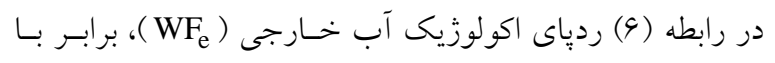

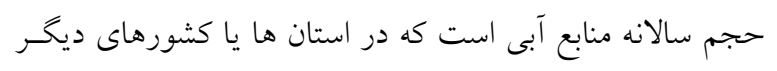

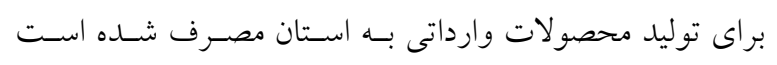

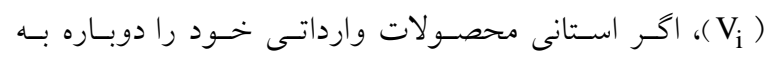

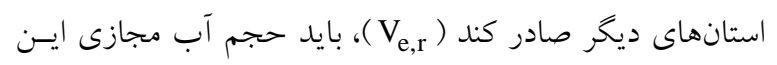

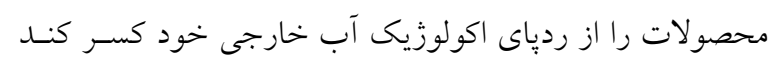

$$
\mathrm{V}_{\mathrm{e}}=\mathrm{V}_{\mathrm{e}, \mathrm{d}}+\mathrm{V}_{\mathrm{e}, \mathrm{r}}
$$




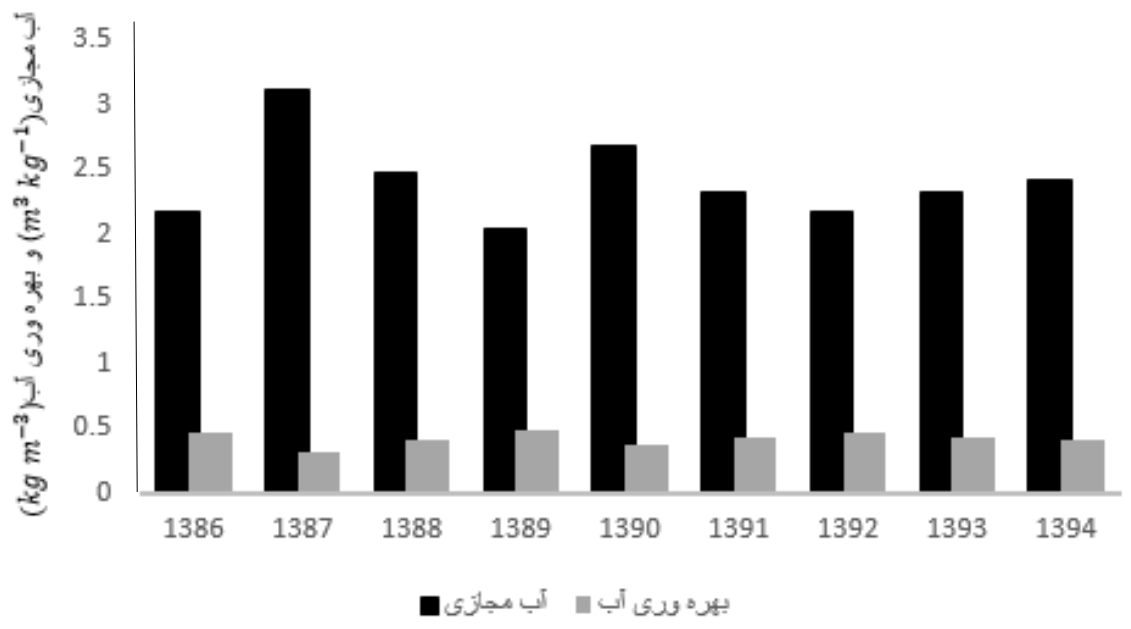

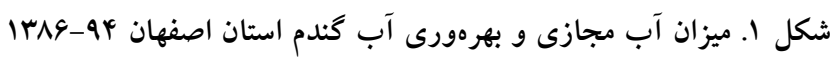

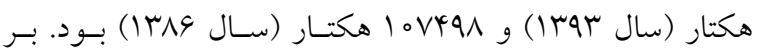

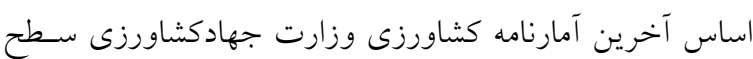

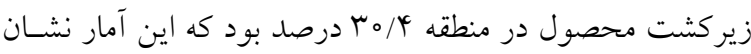
دهنده توليد بالاى اين محصول و همجنين بازده توليسـى بـالاى

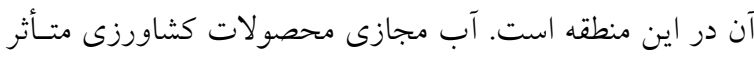

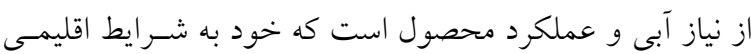

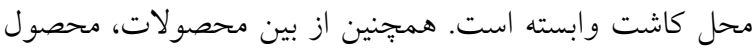

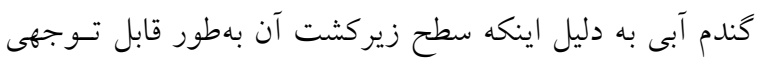

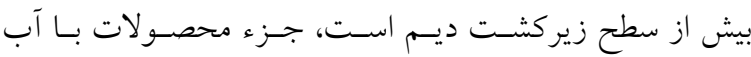

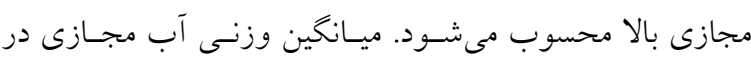

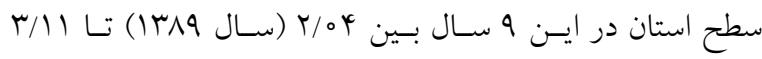

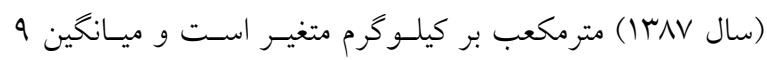

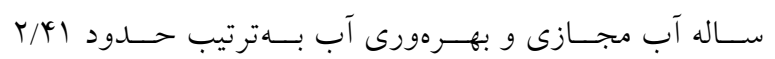

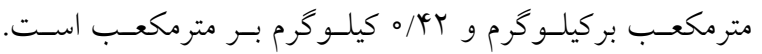
همانطور كه در شكل يك ملاحظه مى شود، بيشترين مقدار آب

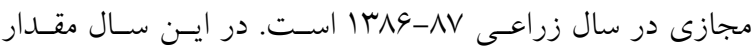

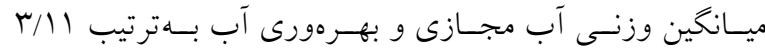

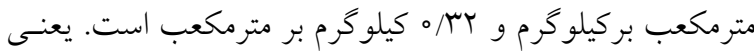

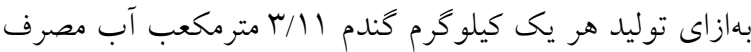
شده و بهازاى هر مترمكعب آب بساه كيلوكرم محصـول توليسـ
شاخص منفى باشد آن منطقه صادركننده آب مجازى است.

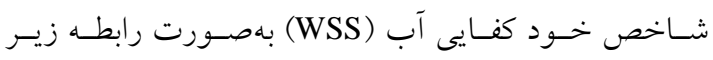
تعريف مىشود: $\mathrm{WSS}=10 \circ-\mathrm{WD}$ اين رابطه برعكس شاخص وابستخى آب است و توانـايى يـى آنس

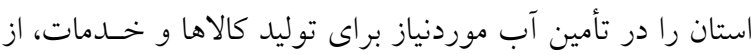

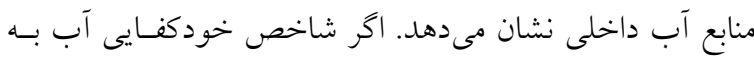

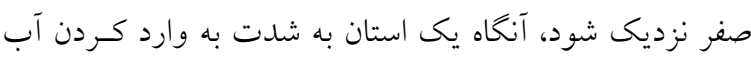
بلهورت مجازى متكى است.

\section{نتايج و بحث}

بر اساس اطلاعات بهدست آمـده آب مجــازى و بهــرهورى آب

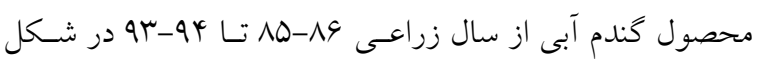

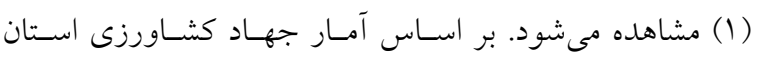

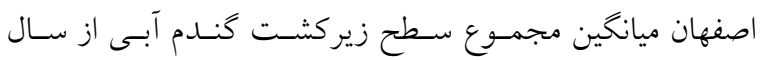

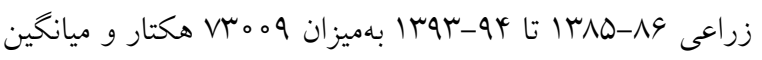

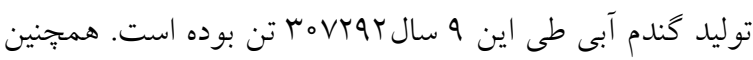

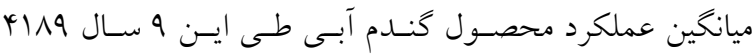

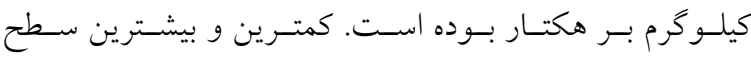

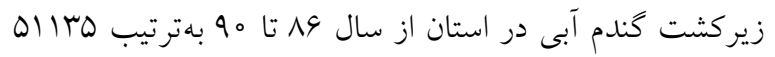


بررسى آب مجازى و ردياى اكولوزيك آب در محصول گندم آبى استان اصفهان

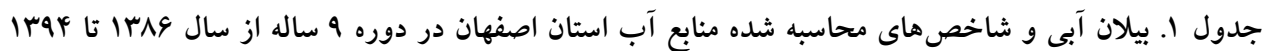

\begin{tabular}{|c|c|c|c|c|c|c|c|c|c|c|}
\hline \multicolumn{10}{|c|}{ سال } & \multirow{2}{*}{ بيلان آبى / شاخص آبى } \\
\hline ميانگين & $1 r q 4$ & 1 rar & 1495 & 11491 & $1 r q_{0}$ & $1 \% \wedge 9$ & IrیA & IrAV & IrNS & \\
\hline$V / V 。$ & $\mathrm{~V} / 9 \mathrm{~V}$ & 9194 & $\mathrm{~V} / \mathrm{M}$ & $\mathrm{V} / \Delta \Delta$ & $V / 9 V$ & $\Lambda / Y_{0}$ & $9 / 00$ & G/VG & $10 / 09$ & 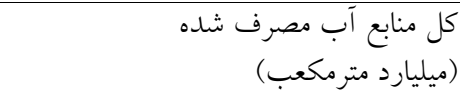 \\
\hline$Q / Y Y$ & $\varphi / \wedge \Delta$ & $Y / Y G$ & $Y / 9 V$ & $r / 9 r$ & $0 / 9 \mathrm{~V}$ & $\Delta / \Gamma \wedge$ & $4 / 90$ & $\Delta / 4 \theta$ & $V / 0 Y$ & كل منابع آب مصرفى در بخش كشاورزى \\
\hline $0 / 0 Y$ & $\circ$ & $\circ$ & $\circ$ & $\circ$ & 。 & 。 & $\circ$ & $\circ$ & $0 / 10$ & (ميليارد مترمكعب آب مجازى در سال) \\
\hline.$/ 90$ & $\circ / \Delta r$ & $1 / \pi r$ & O/AT & $\circ / 0$ & $0 / 99$ & $0 / 14$ & $\circ / V r$ & $1 / 09$ & 。 & (ميليارد مترمكعب اب مجازى در سال) \\
\hline س & $\circ / \Delta r$ & $1 / \pi r$ & O/AY & $\circ / 0$ & $0 / 99$ & $0 / 14$ & $\circ / r^{\mu}$ & $1 / 09$ & $-0 / 10$ & (مبليادد مترمكعب اب مجالص در سالى) \\
\hline$\Delta / \wedge \vee$ & $\Delta / \mu_{\Lambda}$ & $0 / 09$ & $\Delta / V q$ & $Q / F Y$ & $9 / \pi \Delta$ & $Q / \Delta Y$ & $\Delta / r q$ & $9 / 0 Y$ & $9 / 19$ & (ميليارد مترمكع رديا؟ اب در سال) \\
\hline$Q / Y T$ & $Y / \wedge \Delta$ & $Y / Y 4$ & $r / 9 V$ & $r / 9 r$ & $0 / 9 \mathrm{~V}$ & $\Delta / \Gamma \wedge$ & $4 / 90$ & $\Delta / \uparrow \theta$ & $9 / 19$ & (ميليارد مترمكعب اب داخلى در سال) \\
\hline.$/ 90$ & ०/Or & $1 / \pi r$ & o/AT & $\circ / 0$ & $0 / 99$ & $0 / 14$ & $\circ / V r$ & $1 / 09$ & 。 & (ميليارد مترمكعب اب خارجى در سال) \\
\hline$I T \circ V$ & 1.40 & 1099 & 1100 & 1099 & 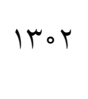 & 1149 & 1114 & 1495 & $14 \wedge 0$ & 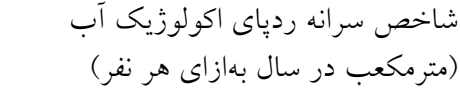 \\
\hline 14 & IT & Ir & 11 & 10 & IT & IV & 10 & 10 & 10 & 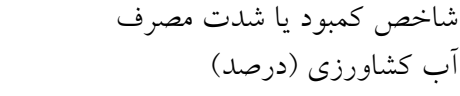 \\
\hline r & IV & $V T$ & 90 & $y_{0}$ & 01 & 14 & 01 & QS & $\circ$ & 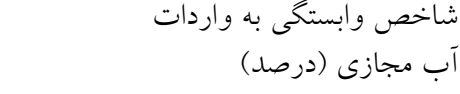 \\
\hline$\Delta V$ & r & TA & $y_{0}$ & 90 & $4 q$ & 19 & 49 & py & 100 & 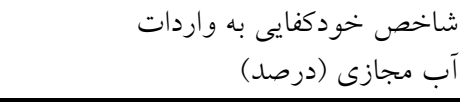 \\
\hline
\end{tabular}

خودكفايى به واردات آب مجازى محصول كندم آبى را از سـال

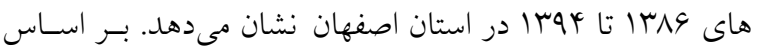
آمار و ارقام بهدست آملده از سازمان آب منطقهاى اسـتان كـه در جدول ( (1) جمع آورى شدهاند، ميانخين 9 ساله بـر آورد كـل آب مصرف شده در استان برابر با V/V0 ميليارد متر مكعب است كه ميانخين سهم آب مصرفى در بخش كشـاورزى در ايسن 9 سـال

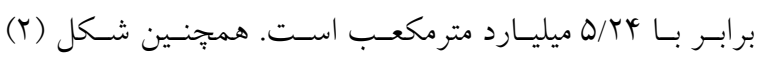
تجارت آب مجازى طى ايسن دوره را بهصـورت نمسودار نشـان مى دها. ميـانكين 9 سـاله صـادرات، واردات و مبادلـه خـالص آب

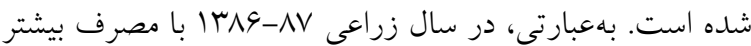
آب، محصول كمتـرى توليسـ شــ. همجنــين طـى ايسن 9 سـال كمترين مقــدار آب مجــازى (Y/OY مترمكعـب بـر كيلـو كرم) و بيشترين ميزان بهرهورى (94/ه كيلوكرم بر مترمكعب) در سـال زراعسى 19-1 1111-19

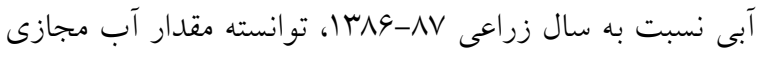
كمترى كه همراه با بهرهورى بيشترى است را بهدست آورد. جدول (1) تراز آب مجازى و نتايج مربسوط بـه محاسـبات شاخصهاى كلى و سرانه ردياى اكولوزيك، كمآبى، وابستخى و 


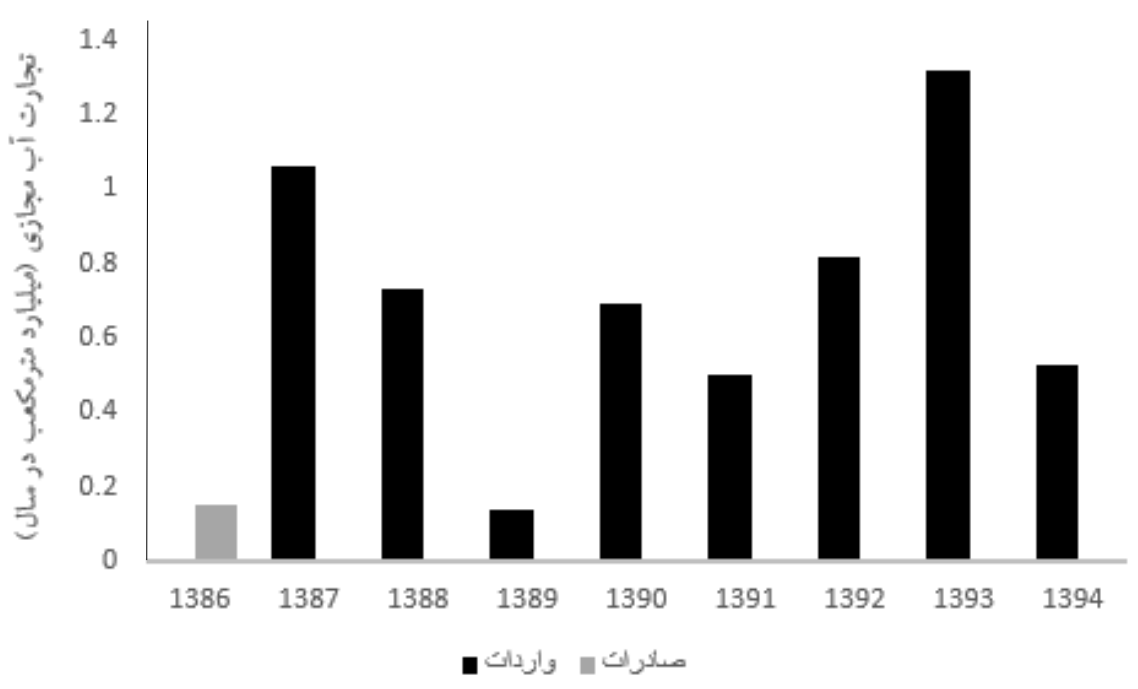

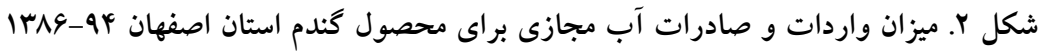

هرسال با استفاده از جمعيت آن سـال محاسـبه شــه اسـت. بـا

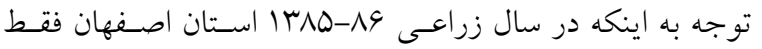
صادركننده بوده، بنابراين اسـتان واردات كنــدم نداشـته كـه بــهـ

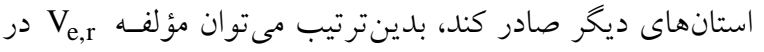
رابطه (9) راصفر فرض كرد. همجنين در سـال هـاى

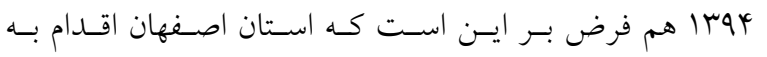

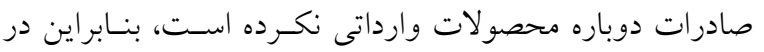

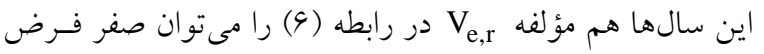

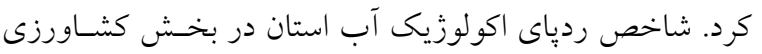

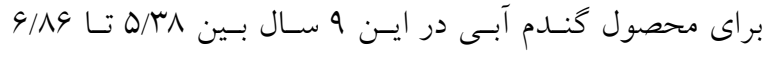

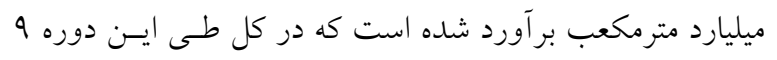

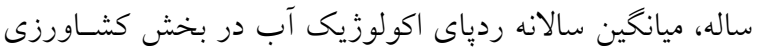
استان D/AV ميليارد مترمكعب بود و استان اصـفهان بـا ميـانخين

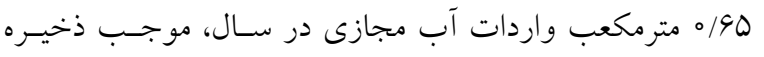

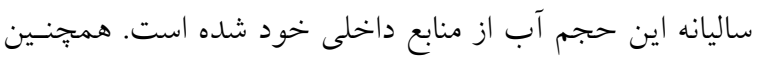

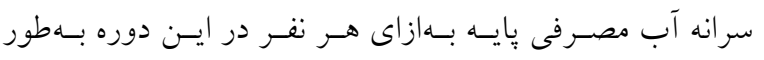

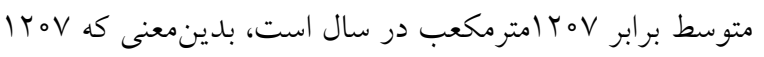

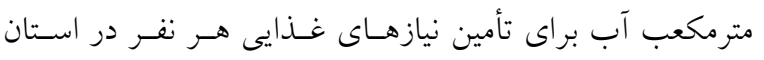
اصفهان مصرف مىشود.

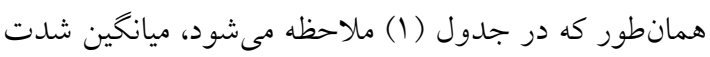

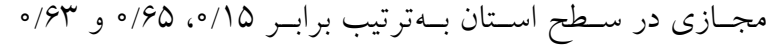
ميليارد مترمكعب بوده است. همانطور كه ملاحظه مسى بـود در

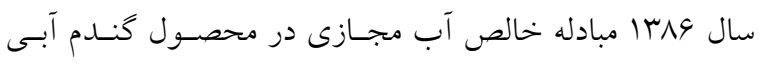

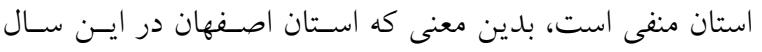

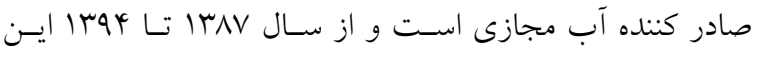
استان واردات آب مجازى در محصول كندم آبى داشته است كه

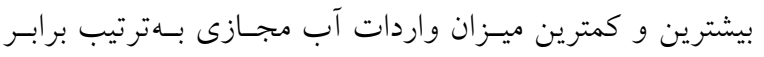

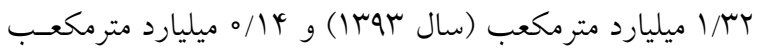

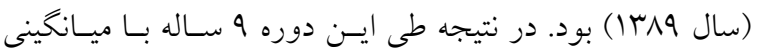
حدود 90/ه ميليـارد مترمكعـب آب مجــازى وارد اسـتان شــده

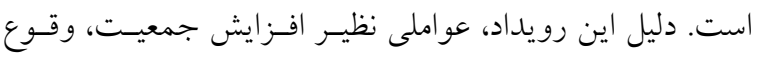

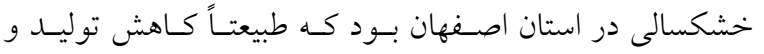

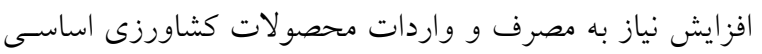

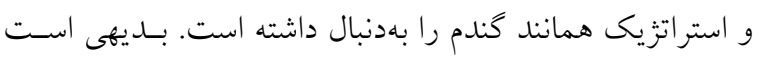
وقوع خشكسالى اخير در استان اصفهان روند توليد و صـادرات

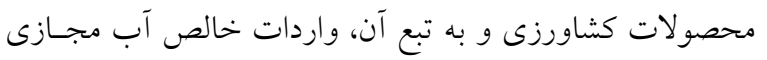
استان را نيز تحت تأثير قرار دادهاست.

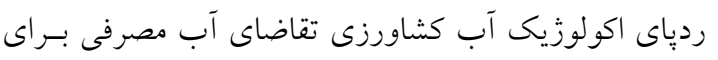

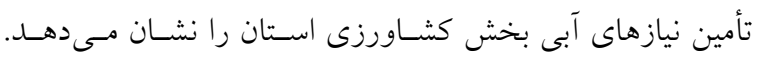

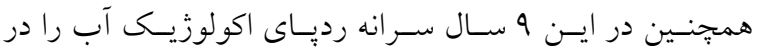


دوره كه استان اصفهان تنها واردكننده آب مجازى بـوده بـهنور

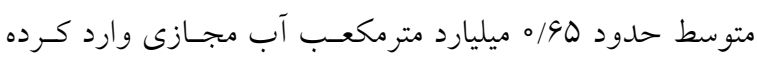

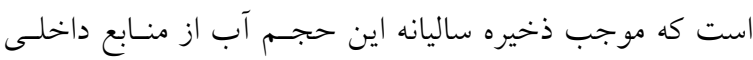

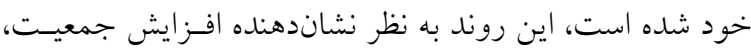

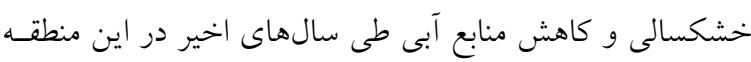

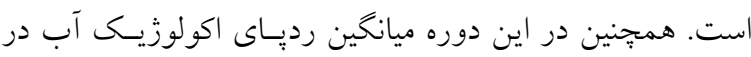
بخش كشاورزى استان براى محصول كُندم برابـر ه/AV ميليسارد

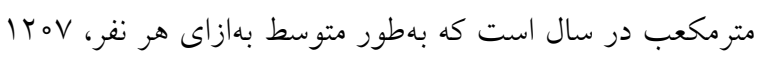

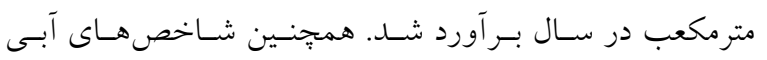
محاسبه شده براى محصول كندم در استان نشان دادند كه بهطور

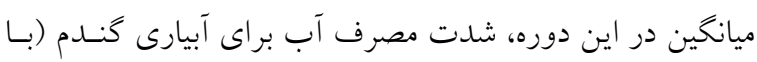

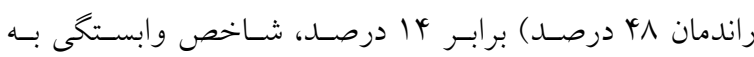

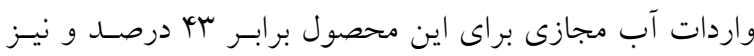

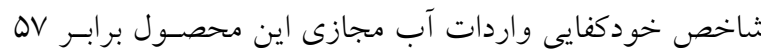
درصد بودهاند.

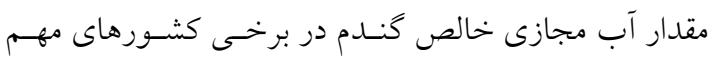
توليدكنتده از جمله استراليا، برزيل، جين، فرانسـه، هنــ، ايــان،

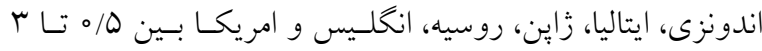

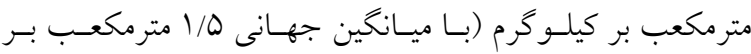

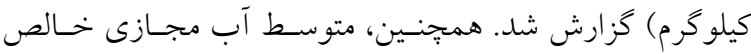

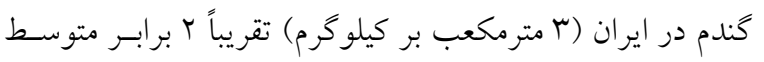

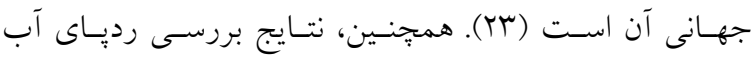

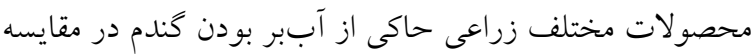

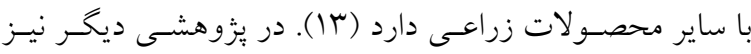

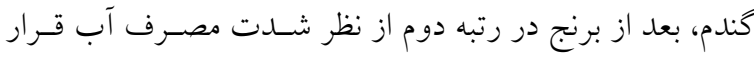
كرفت (1). مطالعهاى كه در استان اصفهان انجام شد در مقايسـهـ با مطالعهاى كه يورجعفرىنزاد و همكاران (TQ) در كرمان انجام دادند تا حدى نزديك به هم بودند. در اين مطالعه بررسى ردياى

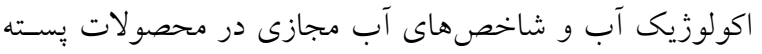

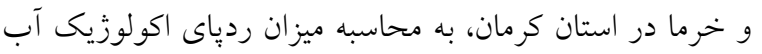
و شاخص هاى آب مجـازى در محصـولات اسـتراتزيكى اسـتان

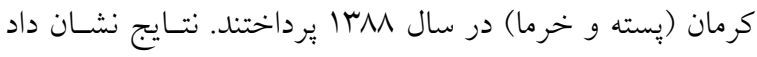

مصرف آب براى محصـول گنــدم آبسى بـا رانـدمان آبيـارى

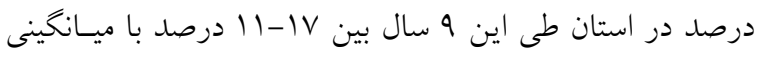

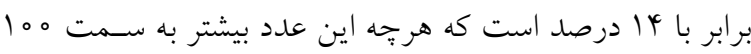

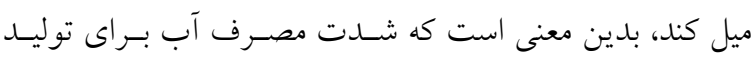

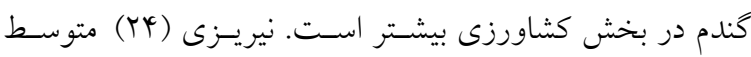

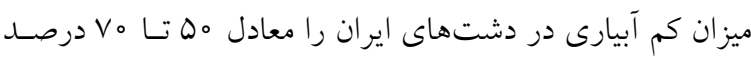

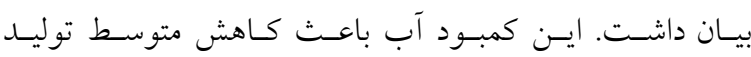

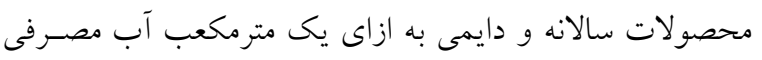

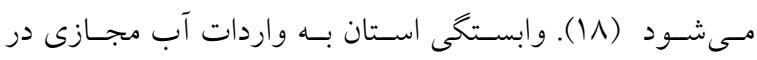

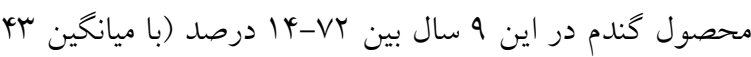

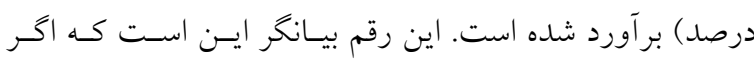

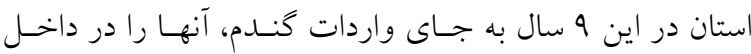

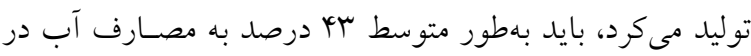

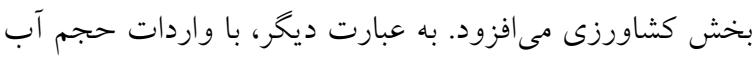
مجازى در اين محصول به استان در طى ايسن سـالهـا، بـهـور

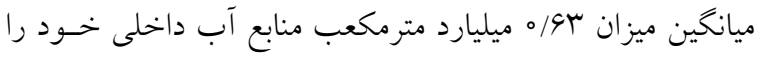

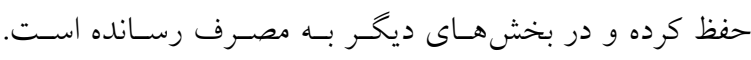

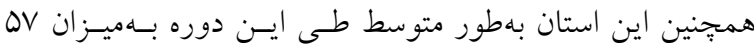

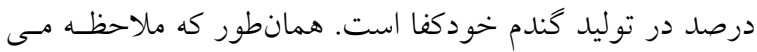

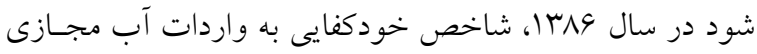
صد در صد است كه بيانكر اين است كسه استـان در ايسن سـال

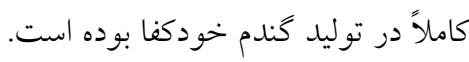

\section{نتيجه كيرى}

در اين يزوهش، به برزسى ردياى اكولوزيك آب، آب مجازى و

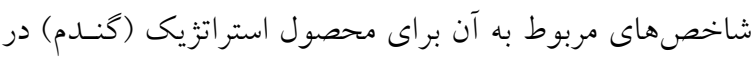

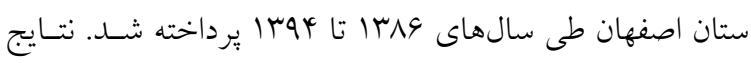

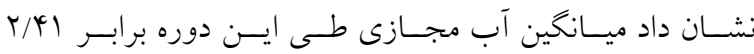

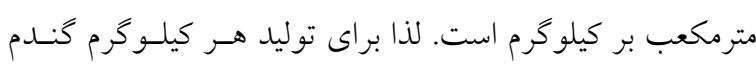

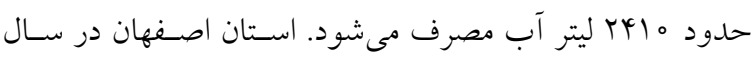

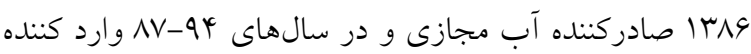
آب مجازى براى محصول كندم بوده است. در نتيجه طسى ايسن 
كه شاخص ردياى اكولوزيك آب استـان در بخـش كشـاورزى شود.

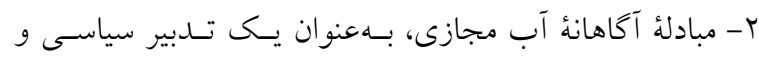

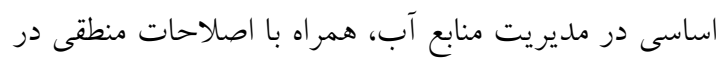

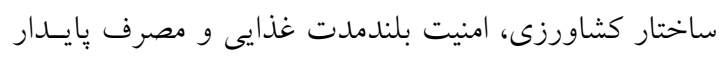

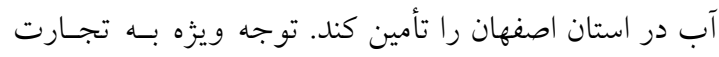

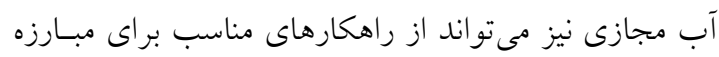

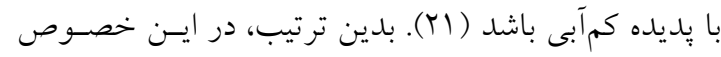

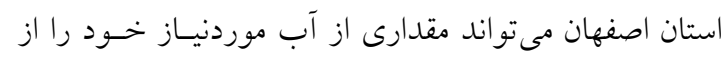

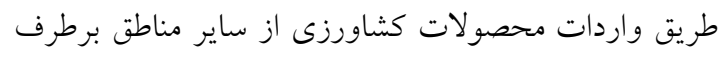

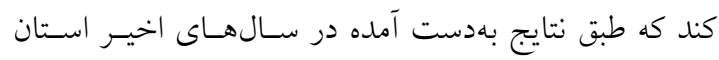

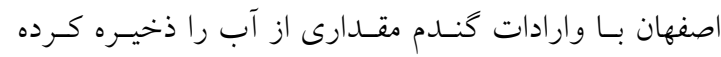

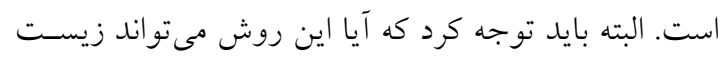

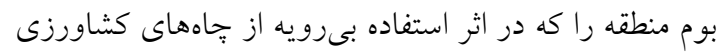
دجار تنش خشكى شده است يارى كند يا خير. r- نتايج اين مطالعه نشان مىدهد كه بر اساس ميانخين 9 سـاله

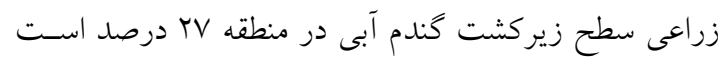

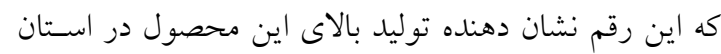

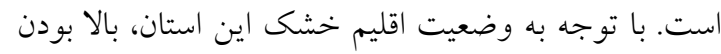

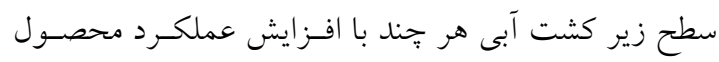

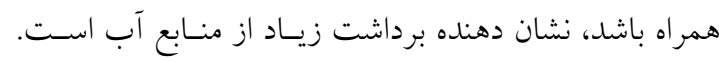

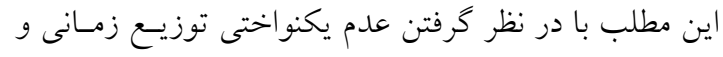

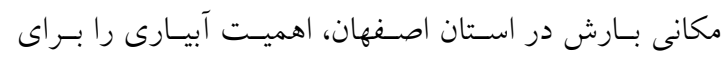

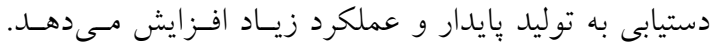

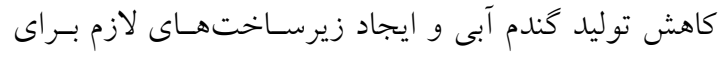

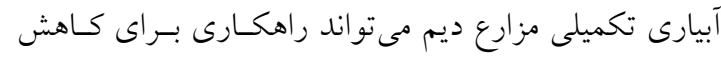
فشار بر منابع آبى منطقه باشد.

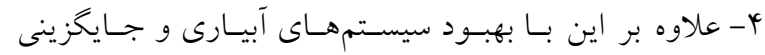

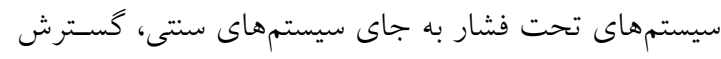

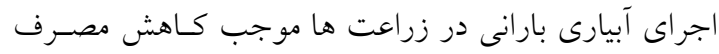

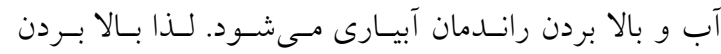

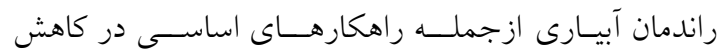
ردياى آب محصولات است.

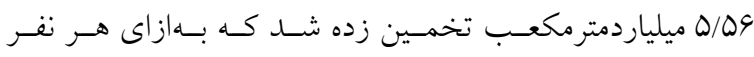
To9V/T يزّوهش حاضر، در ابعاد زمانى و مكانى مختلف (كشور، استـان

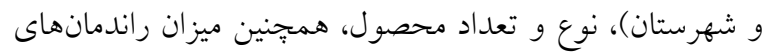

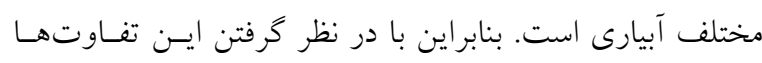

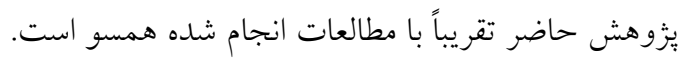

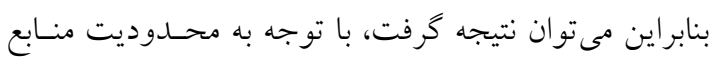

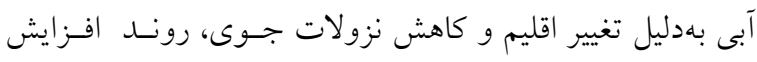

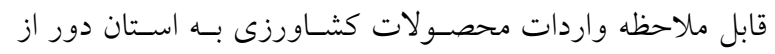
انتظار نيست. لذا، بايستى توجه بيشترى بـه سـاختار كشـاورزى ماته

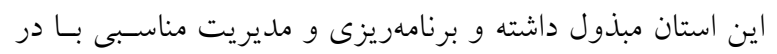

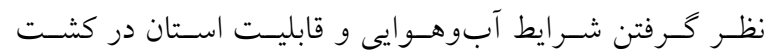

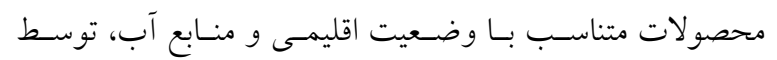

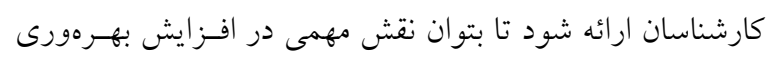

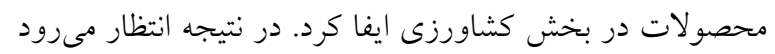

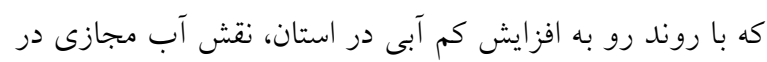
امنيت غذايى، بيوسته افزايش يابد.

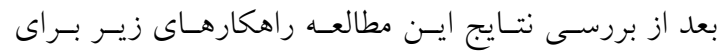

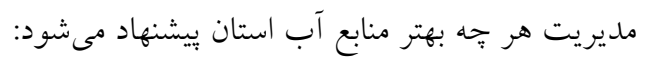

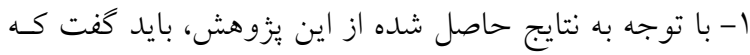

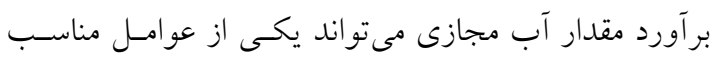
كزينش كشتهاى جـايكزين در منـاطق كشـاورزى اسـتان

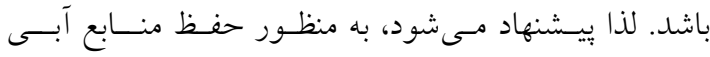
سططى و زيرزمينى در دسترس در اين استان و اسـتففاده

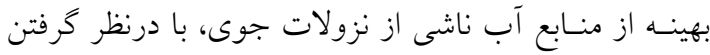
منافع ملــــى و حفظ استقلال سياسى و اقتصادى اســـتان،

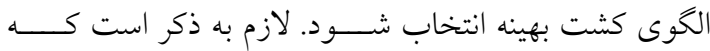

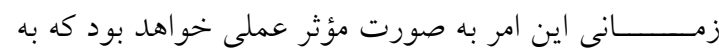

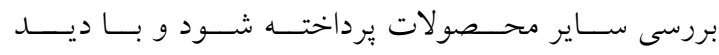

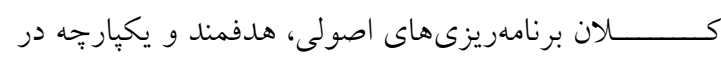

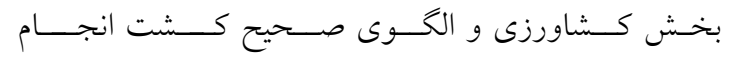




$$
\begin{aligned}
& \text { ه- اصلاح شيوه توليد در بخش كشاورزى و ارتقـاء سـطح بهـره 9- بيشنهاد مىشود اين تحقيق در سـطح تمـام شهرسـتانهـاى } \\
& \text { ورى در مصرف آب يكى از راهكارهاى كـاهش رد يـاى آب استان اصفهان و همجنين بهصورت يكى طرح ملى در سطح } \\
& \text { نيز بهشمار مىرود و بدينترتيب مىتوان به منـابع كـافى آب تمام استانهاى كشور و براى تمامى محصولات كثـاورزى } \\
& \text { براى توليد مواد غذايى دست يافت. از عو امل مؤثر در كاهش انجام كيرد تا ارزيابى وضعيت تمام استانهاى كشور يهنـاور } \\
& \text { شاخص آب مصرفى مردم (آبرانه كشاورزى) اصـلاح الخـوى ايران در مبادلات درونكشـورى آب مجـازى بـهـور كامـل }
\end{aligned}
$$

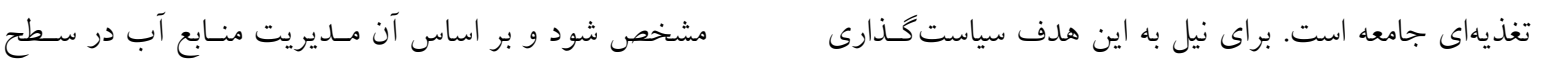

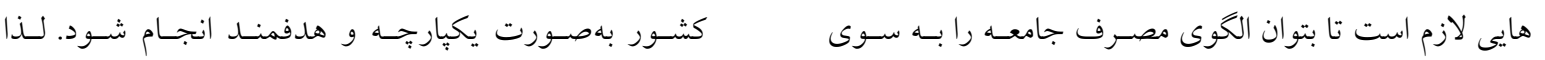

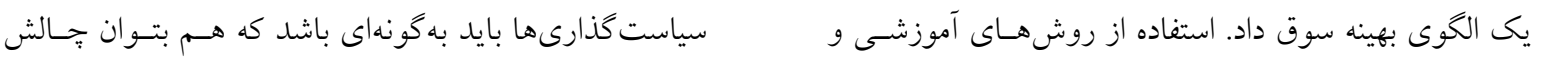

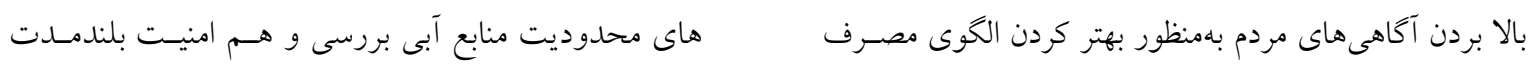

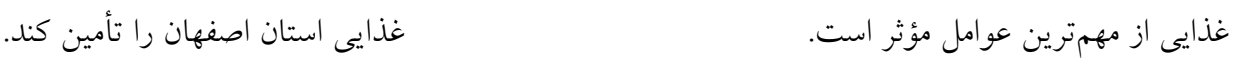

منابع مورد استفاده

1. Aldaya, M., J. Allan and A. Hoekstra 2010. Strategic importance of green water in international crop trade. Ecological Economics 69: 887-894.

2. Aldaya, M. and M. Lamas. 2009. Water footprint analysis (Hydrologic and Economic) of the Guadiana river basin, Published by the United Nations Educational, Scientific and Cultural Organization, 7 place de Fontenoy, 75352 Paris.

3. Allan, J.A. 1993. Fortunately There Are Substitutes for Water Otherwise Our Hydro-Political Futures Would Be Impossible, In: ODA, Priorities for Water Resources Allocation and Management, ODA, London.

4. Arabi-Yazdi, A., A. Alizadeh and F. Mohammadian. 2009. Study on ecological water footprint in agricultural section of Iran. Journal of Water and Soil 23(4): 1-15.

5. Arabi-Yazdi, A., N. Nik nia, N. Majidi and H. Majidi. 2015. Water security assessment in arid climates based on water footprnt concept (case study; south khorasan province). Iranian Journal of Irrigation and Drainage 8(4): 735746.

6. Bulsink, F., A. Hoekstra and M. Booij. 2010. The water footprint of Indonesian provinces related to the consumption of crop products. Hydrology and Earth System Sciences 14: 119-128.

7. Chapagain, A. and A. Hoekstra. 2003. Virtual water flows between nations in relation to trade in livestock and livestock production. Value of Water Research Report Series No. 13. UNESCO. IEIE. Delft, the Netherlands.

8. Chapagain, A., A. Hoekstra and H. Savenije. 2006. Water saving through international trade of Agricultural products. Hydrology Earth System Science 10: 455-468.

9. Chapagain, A., A. Hoekstra, H. Savenije and R. Gautam. 2006. The water footprint of cotton consumption: An assessment of the impact of worldwide consumption of cotton products on the water resources in the cotton producing countries. Ecological Economics 60: 186-203.

10. Ehsani, M. H. Khaledi and Y. Barghi. 2009. Introduction to Virtual Water. Iranian National Committee on Irregation \& Drainage (IRNCID). Tehran.

11. El Sadek, A. 2010. Virtual water trade as a solution for water scarcity in Egypt. Water Resources Management 24(11): 2437-2448.

12. Finger, R. 2013. More than the mean-a note on heterogeneity aspects in the assessment of water footprints. Ecological Indicators 29: 145-147.

13. Hoekstra, A. 2003. Virtual water trade: processing of the international expert meeting on Virtual water trade. Value of the Water Research Report 12: 1-248.

14. Hoekstra, A. and A. Chapagain. 2008. Globalization of Water: Sharing the Planet's Freshwater Resources. Blackwell Publishing, Oxford, UK.

15. Hoekstra, A., A. Chapagain, M. Aldaya and M. Mekonnen. 2009. Water Footprint Manual, State of the art. Water Footprint Network Press. Enschede, the Netherlands.

16. Hoekstra, A. Y. and P. Q. Hung. 2002. Virtual Water Trade: A Quantification of Virtual Water Flows between Nations In Relation To International Crop Trade. Value of Water Research Report Series No. 11, UNESCO-IHE, 
Delft, the Netherlands.

17. Hoekstra, A. Y. 2008. Water Neutral: Reducing and of Setting the Impacts of Water Footprints. Value of Water Research Report Series, NO. 28, Delft, the Netherlands: Unesco-IHE Institute for Water Education.

18. Kaveh, F. 2003. Promoting agricultural water productivity and Food security. In: Proceeding of the The Eleventh National Conference of Iranian National Committee on Irregation \& Drainag. Iran.

19. Khoramivafa, M., M. Nouri, F. Mondani and H. Veisi. 2017. Evaluation of virtual water, water productivity and ecological footprint in wheat and maize farms in west of Iran: A case study of Kouzaran Region, Kermanshah Province. Journal of Water and Sustainable Development 3(2):19-26.

20. Leenesa, W. G., A. Y. Hoekstraa and T. H. Meerb. 2009. The Water Footprint of Bioenergy, PANAS 106(25): 10219-10223.

21. Lenzen, M., A. Bhaduri, D. Moran, K. Kanemoto, M. Bekchanov, A. Geschke and B. Foran. 2012. The role of scarcity in global virtual water flows. Social Science Research Network 169: 1436-9931.

22. Mamanpush, A. 2015. Final Report of the Evaluation Project and Determination of Irrigation Efficiency in Traditional and Modern Irrigation Networks of Isfahan Province. Ministry of Agriculture - Jahad, Promotion Organization, Agriculture Education and Research in Isfahan Province. Iran.

23. Mohammadi, H. and A. Taali Moghadam. 2011. Virtual water trade for major crops in Iran. In: Proceeding of the Second National Conference of Applied Research of Water Resources. Zanjan, Regional Water Company of Zanjan.

24. Neirizi, S. 2003. An analysis of water use efficiency. In: Proceeding of the Eleventh National Conference of Iranian National Committee on Irregation and Drainag. Tehran.

25. Pour jafari nejad, A., A. Alizadeh and A. Neshat. 2013. Study on ecological water footprint and indicators of virtual water in agricultural section of Kerman province. Journal of Irrigation \& Water Engineering 4(13): 80-89.

26. Regional Water Company of Isfahan. Available online at: http://esrw.ir/SC.php?type=static\&id=103.

27. Salari, S., F. Karandish and A. Darzi-Naftchali. 2014. Spatial and temporal analyses of the wheat virtual water variations in Sistan and Blouchestan Province. Journal of Irrigation \& Water Engineering 5(18): 81-94.

28. Van oel, P., M. Mekonnen and A. Hoekstra. 2008. The External Water Footprint of the Netherlands: Quantification and Impact Assessment. Value of Water Research Report Series, No. 33, UNESCO-IHE, Delft, the Netherlands, p. 72.

29. Zarei, GH. and A. M. Jafari. 2015. The role of import and export of major crop productions in virtual water trade and water footprint in agricultural sector of Iran. Iranian Journal of Irrigation and Drainage 9(5): 784-797. 


\title{
Investigation of Virtual Water and Ecological Footprints of Water in Wheat Fields of Isfahan Province
}

\author{
F. Oveisi, A. Fattahi Ardakani* and M. Fehresti Sani ${ }^{1}$
}

(Received: December 29-2017; Accepted: March 10-2018)

\begin{abstract}
Despite the recent droughts in Isfahan province, climatic changes and the rising trend of population growth, as well as development of industrial and agricultural activities, are exposed to the water crisis. Thus, in order to tackle this problem, the essential strategies should including exploring virtual water and water foot print for strategic crops in agricultural sector should be taken into consideration for the management of water supplies at risk. This study was aimed to examine virtual water and ecologic fingerprint of water for the wheat crop in Isfahan Province from the farming year 2006-7 through 2014-15. For this purpose, the quantity of virtual water was extracted using net irrigation demand by NETWAT software and the rate of irrigation efficiency was computed to be $48 \%$. The results indicated that only in 2007, Isfahan province was an exporter of virtual water for the wheat crop, so this province exported about 0.15 billion cubic meters of virtual water to other provinces by wheat exportation, but Isfahan province was the only virtual water in the years (2008-15) and this was due to the annual population rise and the existing drought in this zone. During this period, the rate of the mean annual rate of ecological footprint of water was 5.87 billion cubic meters and Isfahan Province stored this volume of water from the given internal supplies annually, with the mean rate of 0.65 billion cubic meters of virtual water importation at that year.
\end{abstract}

Keywords: Crop Water Productivity, Consumption intensity index, Dependence index, Self-sufficiency index, Virtual water trade

1. Department of Agricultural Economics, Faculty of Natural Resources, Ardakan University, Ardakan, Iran.

*: Corresponding Author, Email: fatahi@ardakan.ac.ir 